\title{
Hepatitis B and C Viral Infections in Patients with Hepatocellular Carcinoma
}

\author{
Juan Ruiz, ${ }^{1,2}$ Bruno SAngro, ${ }^{1,2}$ José I. Cuende, ${ }^{1}$ OsCAR Beloqui, ${ }^{1,2}$ José I. Riezu-BoJ, ${ }^{1}$ \\ José I. HERrero ${ }^{1,2}$ AND JEsús PRIETO ${ }^{1,2}$ \\ ${ }^{1}$ Center of Biomedical Research, Department of Medicine and ${ }^{2}$ Liver Unit, Clínica Universitaria, Universidad de Navarra, \\ 31080 Pamplona, Spain
}

\begin{abstract}
The prevalence of hepatitis $B$ and $C$ virus infections was studied in 70 patients diagnosed as having hepatocellular carcinoma. In addition to viral serological markers, serum hepatitis $B$ virus DNA and hepatitis $C$ virus RNA were determined with a nested polymerase chain reaction assay. Twelve patients $(17 \%)$ were HBsAg positive, 26 (37\%) had antibodies to HBs, HBc or both and $32(46 \%)$ were negative for all hepatitis $B$ virus serological markers. Prevalence of the antibody to hepatitis C virus was 63\% (44 patients). Hepatitis B virus DNA was detected in 24 of the 66 tested patients $(36 \%)$. Twelve of these hepatitis B virus DNA-positive patients were HBsAg negative (seven were positive for antibody to HBs, antibody to HBc or both and five were negative for all hepatitis $B$ virus serological markers). Hepatitis $C$ virus RNA was found in 42 of 68 patients $(62 \%)$. A high correlation (95\%) existed between hepatitis $C$ virus RNA and hepatitis $C$ virus antibodies. Nevertheless, two patients without antibody to hepatitis $C$ virus had serum hepatitis $C$ virus RNA sequences. Coinfection by the two viruses was detected in nine subjects (14\%), but no clinical differences were found between these and the rest of the patients. We conclude that nearly $90 \%$ (62 of the 70 patients studied) of cases of hepatocellular carcinoma in our geographical area are related to hepatitis virus infections (detected by serological or molecular studies). Hepatitis $\mathbf{C}$ is more prevalent than hepatitis $B$ virus in patients with hepatocellular carcinoma, and the infection is still active when the tumor is diagnosed. This fact is probably important in the contribution of hepatitis $\mathrm{C}$ virus to the development of hepatocellular carcinoma. (HEPATOLOGY 1992;16:637-641.)
\end{abstract}

Interest in HCC derives not only from its worldwide incidence but also from evidence implicating hepatitis viruses in its development. Molecular, epidemiological and clinical studies have confirmed the strong associ-

Received December 26, 1991; accepted April 20, 1992

This work was supported in part by the Fundation Areces of Spain and by a grant from the Comisión Interministerial de Ciencia y Tecnología (SAL 89-1057) of Spain.

Address reprint requests to: Prof. J. Prieto, Centro de Investigaciones Biomédicas, Departamento de Medicina Interna, Clínica Universitaria, 31080 Pamplona, Spain.

$\mathbf{3 1 / 1} / \mathbf{3 8 9 6 6}$ ation that exists between chronic HBV infection and the occurrence of primary liver tumors (1).

Since the discovery in 1989 of the hepatitis C virus (HCV) (2), the agent responsible for most cases of non-A, non-B hepatitis (NANBH), the prevalence of this virus in various liver diseases has been studied. Thus a growing body of evidence has implicated HCV in the pathogenesis of HCC (3-5). In fact, the carcinogenetic role of HCV appears to be more important than that of the HBV (6). However, detection of HCV antibodies (anti-HCV) does not necessarily indicate the presence of the virus, and neither the real status of the HCV infection nor the relationship between HBV and HCV infections in patients with HCC has been reported until now.

The aim of this study was to analyze the relative role of HBV and HCV infections in the same group of patients with $\mathrm{HCC}$ by both serological tests and a polymerase chain reaction (PCR) assay to detect the presence of genomic sequences of the two viruses in serum.

\section{PATIENTS AND METHODS}

Patients. Seventy patients with primary liver cancer admitted between November 1986 and June 1991 to the Liver Unit of the University Clinic of Navarra were studied consecutively. The clinical features of these patients are summarized in Table 1. The group comprised 55 men and 15 women; mean age was $61.8 \mathrm{yr}$ (range $=36$ to $84 \mathrm{yr}$ ). Cirrhosis was found in 65 patients, CAH was found in 1 patient and the remaining 4 patients had otherwise normal livers. Ten patients had histories of blood transfusion (6 to $41 \mathrm{yr}$ before diagnosis of $\mathrm{HCC}$ ), and $19 \mathrm{had}$ histories of alcohol abuse ( $>80 \mathrm{gm} /$ day). The diagnosis of HCC was made clinically in 9 patients and histologically in the other 61 (21 cases by liver biopsy, 39 by fine-needle aspiration and cytology and 1 case at necropsy). The use of clinical material for this study was approved by the local ethics committee. All serum samples were aliquoted and stored at $-40^{\circ} \mathrm{C}$ until they were used.

Viral Markers. $\mathrm{HBsAg}, \mathrm{HBeAg}$ and antibodies to $\mathrm{HBs}, \mathrm{HBc}$ and $\mathrm{HBe}$ were determined with commercially available RIAs (Abbott Laboratories, Chicago, IL). Anti-HCV was detected in serum by a new second-generation ELISA recently developed by Wellcome Diagnostics (Beckenham, Kent, UK). This assay is based on a recombinant protein (BHC10) that incorporates structural and nonstructural viral antigens (7). 
TABLE 1. Clinical characteristics of patients with HCC

\begin{tabular}{lc}
\hline \multicolumn{1}{c}{ Variable } & $\begin{array}{c}\text { No. of } \\
\text { patients }^{\boldsymbol{a}}\end{array}$ \\
\hline Sex (M/F) & $55 / 15$ \\
Alcohol history (> 80 gm/day) & $19(27)$ \\
History of blood transfusion & $10(14)$ \\
AFP (ng/ml) & \\
$\quad$ Normal (<5) & $17 / 64(27)$ \\
$5-100$ & $16 / 64(25)$ \\
100-500 & $17 / 64(26)$ \\
$>$ 500 & $14 / 64(22)$ \\
Nontumorous liver histological appearance & \\
Normal & $4(6)$ \\
CAH & $1(1)$ \\
Cirrhosis & $65(93)$ \\
Child-Pugh class & \\
A & $27 / 65(41)$ \\
B & $22 / 65(34)$ \\
C & $16 / 65(25)$ \\
Okuda staging & \\
I & $21 / 65(32)$ \\
II & $34 / 65(52)$ \\
III & $10 / 65(15)$ \\
Tumor diagnosis during follow-up of chronic & $19(27)$ \\
liver disease & \\
\hline
\end{tabular}

AFP $=$ alpha-fetoprotein.

${ }^{a}$ Numbers in parentheses are percentages.

Oligonucleotide Primers. Amplification was performed with nested PCR for HBV DNA and a reverse-transcription-PCR (RT-PCR) for HCV RNA. Primers for HBV amplification were designed from the $S$ region with the help of a computer program (Ampli-PCR, Cuende JI, Pamplona, Spain) based on the different $\mathrm{HBV}$ published sequences. The outer primers were HBV-S1 (5' AGAATCCTCACAATACCGCA, sense), starting at map position 222, and HBV-S2 (5' CCCCAA'TACCACATCATCCA, antisense), starting at map position 757 . The inner primers were HBV-S3 (5' TCCAATCACTCACCAACCTC, sense), starting at map position 324 , and HBV-S4 (5' CCC'TACGAACCACTGAACAA, antisense), starting at map position 707 (8). A set of primers described previously (NCR1, NCR2, NCR3 and NCR4) (Garson JA, et al. Lancet 1990;336:878-879, Correspondence) from the highly conserved $5^{\prime}$ non-coding region was used for the HCV amplification.

HBV DNA Extraction and PCR. Two hundred microliters of serum was mixed with $50 \mu \mathrm{l} 2 \%$ SDS and $200 \mu \mathrm{l} 1 \mathrm{mg} / \mathrm{ml}$ proteinase $\mathrm{K}$ and digested at $56^{\circ} \mathrm{C}$ overnight. DNA was then purified by phenol-chloroform extraction, precipitated with absolute ethanol and resuspended in sterile distilled water. The first round of the amplification reaction was carried out in a total volume of $80 \mu \mathrm{l}$ containing $50 \mu \mathrm{l}$ of the DNA extracted, 2.5 units of recombinant Taq DNA Polymerase (Ampli-Taq; Perkin-Elmer Cetus, Norwalk, CT), $30 \mathrm{ng}$ of each outer primer (HBV-S1 and HBV-S2), $0.2 \mathrm{mmol} / \mathrm{L}$ of each dNTP, $50 \mathrm{mmol} / \mathrm{L}$ $\mathrm{KCl}, 10 \mathrm{mmol} / \mathrm{L}$ Tris-HCl (pH 8.3), $1.5 \mathrm{mmol} / \mathrm{L} \mathrm{MgCl}_{2}$ and $0.01 \%$ (wt/vol) dithiothreitol. Reaction mixtures were overlaid with $100 \mu \mathrm{l}$ mineral oil to prevent evaporation. After an initial 5 -min denaturation step at $95^{\circ} \mathrm{C}, 30$ cycles at $95^{\circ} \mathrm{C}$ for $60 \mathrm{sec}$, $60^{\circ} \mathrm{C}$ for $60 \mathrm{sec}$ and $72^{\circ} \mathrm{C}$ for $90 \mathrm{sec}$ were performed. One microliter of the PCR product was reamplified in the second round of the nested PCR in $50 \mu$ l total volume under the same buffer and cycle conditions with the inner primers (HBV-S3 and HBV-S4). Fifteen microliters of the second-round PCR product was analyzed with $2 \%$ agarose gel electrophoresis and visualization by $U V$ fluorescence after ethidium bromide staining.

HCV RNA Extraction and RT-PCR. RNA was extracted by the polyethylene glycol/SDS method as described previously (9), with some modifications: $50 \mu$ l of serum was brought to a final volume of $1 \mathrm{ml}$ with sterile distilled water, and $500 \mu \mathrm{l}$ of $30 \%$ (wt/vol) polyethylene glycol 8000 in $0.1 \mathrm{~mol} / \mathrm{L} \mathrm{NaCl}$ was added. After incubation on ice for $40 \mathrm{~min}$, the mixture was centrifuged $(15,000 \mathrm{~g}$ for $15 \mathrm{~min})$ and the pellet was resuspended in $330 \mu \mathrm{l}$ of $1 \%$ SDS by agitation. Proteins were removed by phenol extraction, and RNA was precipitated with absolute ethanol overnight at $-40^{\circ} \mathrm{C}$. The pellet was resuspended in $80 \mu \mathrm{l}$ of the complementary DNA reaction buffer containing 200 units of cloned Moloney murine leukemia virus reverse transcriptase (BRL, Gaithersburg, MD), 20 units of ribonuclease inhibitor (Pharmacia LKB Biotechnology, Uppsala, Sweden), $5 \mathrm{mmol} / \mathrm{L}$ HEPES-HCl (pH 6.9), $50 \mathrm{mmol} / \mathrm{L}$ Tris-HCl (pH 7.5), $75 \mathrm{mmol} / \mathrm{L} \mathrm{KCl,} 3 \mathrm{mmol} / \mathrm{L} \mathrm{MgCl}_{2}, 10$ $\mathrm{mmol} / \mathrm{L}$ dithiothreitol, $0.125 \mathrm{mmol} / \mathrm{L}$ of each $\mathrm{dNTP}$ and 0.15 $\mathrm{mmol} / \mathrm{L}$ of random primers. Reaction mixtures were overlaid with $100 \mu \mathrm{l}$ mineral oil, incubated first for $45 \mathrm{~min}$ at $42^{\circ} \mathrm{C}$ and followed by $5 \mathrm{~min}$ at $95^{\circ} \mathrm{C}$ and chilled on ice. Twenty microliters of the complementary DNA product was used for nested PCR. The first round of amplification was carried out in a total volume of $50 \mu \mathrm{l}$ containing 2.5 units of cloned Taq DNA Polymerase, $30 \mathrm{ng}$ of each outer primer (NCR1 and NCR2), $0.2 \mathrm{mmol} / \mathrm{L}$ of each dNTP, $50 \mathrm{mmol} / \mathrm{L} \mathrm{KCl,} 10 \mathrm{mmol} / \mathrm{L}$ Tris- $\mathrm{HCl}$ (pH 8.3), $1.5 \mathrm{mmol} / \mathrm{L} \mathrm{MgCl}_{2}$ and $0.01 \%$ dithiothreitol. The cycle profile consisted of a 5 -min denaturation step at $95^{\circ} \mathrm{C}$ followed by 35 cycles at $95^{\circ} \mathrm{C}$ for $60 \mathrm{sec}, 50^{\circ} \mathrm{C}$ for $60 \mathrm{sec}$ and $72^{\circ} \mathrm{C}$ for $90 \mathrm{sec}$. One microliter of the first PCR product was amplified in the second round with the inner primers (NCR3 and NCR4) under the same buffer and cycle conditions except for the number of cycles (30 cycles) and the annealing temperature $\left(46^{\circ} \mathrm{C}\right)$. Results were analyzed, as in HBV PCR, by electrophoresis of $15 \mu l$ of the second-round PCR product.

Precautions and Controls. To avoid possible false-positive results, the recommendations of Kwok and Higuchi (10) were strictly followed. Extraction and amplification were performed in separate rooms; positive displacement pipettes were used; solutions were prepared in a PCR product-free environment, autoclaved and stored in aliquots that were used only once; and DNA samples were added last to each tube. Thirty-one serum samples from anti-HCV-negative subjects vaccinated against $\mathrm{HBV}$ were used as negative controls and subjected to the entire process of extraction, reverse transcription (in the case of $\mathrm{HCV}$ RNA determination) and amplification, in parallel with the test samples. To detect cross-contamination, "non-DNA" controls (PCR mix without template DNA) were included for every test sample during the amplification process. Each sample was tested at least twice, and most tests were repeated three times to confirm the validity of our results.

\section{RESULTS}

Twelve of the 70 patients tested (17\%) were $\mathrm{HBsAg}$ positive. Antibodies to $\mathrm{HBs}$ and $\mathrm{HBc}$ were found in 26 (37\%) patients; 32 (46\%) had no HBV serological markers. HBeAg was detected in two of the HBsAgpositive patients. Anti-HCV was present in $44(63 \%)$ cases. The relationship between $\mathrm{HBV}$ and HCV serological data is shown in Table 2 . It is noteworthy that none of the HBsAg-positive patients had anti-HCV, 
Table 2. Prevalence and relationship of anti-HCV and serological markers of $\mathrm{HBV}$ infections in patients with $\mathrm{HCC}$

\begin{tabular}{lccc}
\hline HBV status & $\begin{array}{c}\text { Anti-HCV } \\
\text { positive (\%) }\end{array}$ & $\begin{array}{c}\text { Anti-HCV } \\
\text { negative (\%) }\end{array}$ & Total (\%) \\
\hline HBsAg positive & $0(0)$ & $12(17)$ & $12(17)$ \\
Anti-HBs and/or & $23(33)$ & $3(4)$ & $26(37)$ \\
$\quad$ anti-HBc positive & & & \\
HBV negative & $21(30)$ & $11(16)$ & $32(46)$ \\
TOTAL & $44(63)$ & $26(37)$ & 70 \\
\hline
\end{tabular}

Anti-HBs = antibody to $\mathrm{HBs} ;$ anti-HBc $=$ antibody to $\mathrm{HBc}$.

whereas 23 of the 26 patients with antibodies to HBs or $\mathrm{HBc}$ were anti-HCV positive. No serological markers of HBV or HCV infection were found in 11 patients $(16 \%)$. Nine of the 10 patients with histories of blood transfusion were anti-HCV positive.

Detection of $\mathrm{HBV}$ in Serum. Sera from 66 patients were analyzed for the presence of circulating HBV DNA sequences as detected by amplification of the $\mathrm{S}$ region. Serum HBV DNA was positive in 24 patients ( $36 \%$ ). This group included all $12 \mathrm{HBsAg}$-positive patients. Of the remaining HBV DNA-positive cases, seven patients had antibodies to $\mathrm{HBs}$ or antibodies to $\mathrm{HBc}$ and five were negative for all HBV serological markers $(30 \%$ and $16 \%$, respectively, of each serological group [Fig. 1A, Table 3]).

Detection of HCV in Serum. Of the 68 patients studied, $42(62 \%)$ had HCV sequences in serum (Fig. 1B, Table 3). HCV RNA was found in 40 of the 42 anti-HCV-positive tested patients (95\%). On the other hand, two patients without anti-HCV tested positive on PCR. Interestingly, one of these seronegative patients had had blood transfusions on two different occasions (33 and $10 \mathrm{yr}$ before diagnosis of HCC).

On combination of the results of $\mathrm{HBV}$ and $\mathrm{HCV}$ testing, coinfection by the two viruses as detected by PCR was found in nine patients (Table 3). All were anti-HCV positive, and six had antibodies to HBs, HBc or both. Of the 11 patients negative for both HBV and HCV serological markers, 1 was positive for serum HBV DNA and another 2 were positive for HCV RNA. Therefore in only 8 of the 70 patients tested $(11 \%)$ could HCC not be related to HBV or HCV infection by serological study, PCR study or both. Three of these patients with nonviral HCC had alcoholic cirrhosis; another had cirrhosis caused by idiopatic hemochromatosis. In the remaining four patients, the nontumorous liver was histologically normal and no risk factors could be identified.

\section{DISCUSSION}

Evidence implicating non-A, non-B agents in the development of HCC appeared before the discovery of HCV, when Ayoola, Odelola and Johnson (11) and Resnick, Stone and Antonioli (12) reported HCC in a patient with community-acquired NANBH and HCC after posttransfusion NANBH (PTNANBH), respectively. Soon, epidemiological studies showed a relationship between PTNANBH and HCC (13-15). These

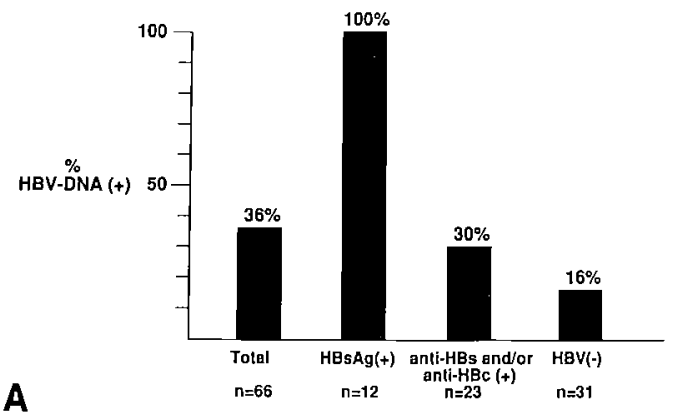

A

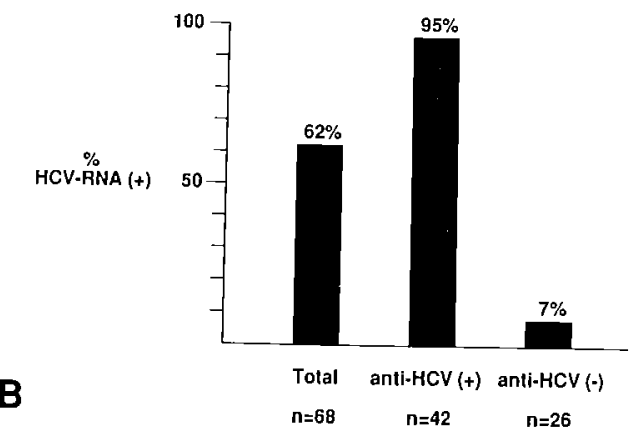

FIG. 1. Results of the detection by PCR and RT-PCR of (A) HBV DNA and (B) HCV RNA in patients with HCC. $H B V(-)=$ negative for all $\mathrm{HBV}$ serological markers.

epidemiological associations were confirmed when in 1989 Choo et al. $(2,16)$ cloned the agent of NANBH and developed a specific serological assay to detect this agent, designated HCV. Since then, several authors have established that the prevalence of anti-HCV in patients with HCC is $60 \%$ to $70 \%$ (3-5). Furthermore, it has been postulated that the role of HCV could be more important than that of chronic HBV infection (6). Nevertheless, little is known about the biology of HCV infection, and the mechanism by which HCV could contribute to the pathogenesis of HCC remains unknown. Previous studies of PTNANBH have shown the detection of anti-HCV during the transition from acute hepatitis to HCC (17). Moreover, Farci et al. (18) recently described the HCV replication status in five patients with acute and chronic PTNANBH, finding serum HCV RNA in patients with the chronic form throughout the follow-up (10 to $14 \mathrm{yr}$ ).

In this study we found that $62 \%$ of our patients with HCC ( 42 of 68 cases tested) had detectable HCV genome sequences in their serum at the time of diagnosis. Moreover, we demonstrated HCV viremia in two patients who received transfusions as long as 40 and $41 \mathrm{yr}$ before development of HCC. Thus (although this is not a direct derivation from our results) it seems that HCV infection remains active for very long periods of time, and persistent viremia could be the rule when HCV infection progresses from acute hepatitis to chronic hepatitis, liver cirrhosis and, finally, HCC. Although demonstration of genome integration (as in HBV infection), has failed until now, it is reasonable to suppose 
TABLE 3. Results of serological and PCR testing for hepatitis $C$ and $B$ viruses in patients with $H C C$

\begin{tabular}{|c|c|c|c|c|c|}
\hline Anti-HCV & HBV markers & $\begin{array}{c}\text { No. of } \\
\text { patients with } \\
\text { markers }(\%)\end{array}$ & $\begin{array}{c}\text { HCV RNA (no. } \\
\text { positive/no. tested) }\end{array}$ & $\begin{array}{c}\text { HBV DNA (no. } \\
\text { positive/no. tested) }\end{array}$ & $\begin{array}{c}\text { HCV } \\
\text { RNA/HBV DNA } \\
\text { (no. positive/no. } \\
\text { tested) }\end{array}$ \\
\hline \multirow{4}{*}{$\begin{array}{l}\text { Anti-HCV positive } \\
(\mathrm{n}=44 ; 63 \%)\end{array}$} & $\mathrm{HBsAg}$ & $0(0)$ & 0 & 0 & 0 \\
\hline & $\begin{array}{l}\text { Anti-HBs and/or anti-HBc } \\
\text { positive }\end{array}$ & $23(33)$ & $21 / 22$ & $6 / 20$ & $6 / 18$ \\
\hline & HBV negative & $21(30)$ & $19 / 20$ & $4 / 20$ & $3 / 19$ \\
\hline & $\mathrm{HBsAg}$ & $12(17)$ & $0 / 12$ & $12 / 12$ & $0 / 12$ \\
\hline \multirow[t]{2}{*}{$\begin{array}{l}\text { Anti-HCV negative } \\
\quad(\mathrm{n}=26 ; 37 \%)\end{array}$} & $\begin{array}{l}\text { Anti-HBs and/or anti-HBc } \\
\text { positive }\end{array}$ & $3(4)$ & $0 / 3$ & $1 / 3$ & $0 / 3$ \\
\hline & HBV negative & $11(16)$ & $2 / 11$ & $1 / 11$ & $0 / 11$ \\
\hline TOTAL & - & 70 & $42 / 68$ & $24 / 66$ & $9 / 63$ \\
\hline
\end{tabular}

Anti-HBs = antibody to $\mathrm{HBs}$; anti-HBc = antibody to $\mathrm{HBc}$.

that continuous liver damage and cirrhosis are the most likely mechanisms by which HCV contributes to the pathogenesis of HCC. Supporting this hypothesis is the fact that all but one of our anti-HCV-positive and/or HCV RNA-positive patients had cirrhosis (the noncirrhotic patient had $\mathrm{CAH}$ ).

A high correlation between anti-HCV assay results and PCR results has been observed in our series. Forty of the 42 anti-HCV-positive patients (95\%) had HCV RNA in their serum; by contrast, only 2 patients exhibited serum HCV sequences in the group of 26 patients negative for antibodies to $\mathrm{HCV}(7 \%)$. In fact, one of these two patients had had blood transfusions on two different occasions (33 and $10 \mathrm{yr}$ before tumor diagnosis). The existence of a fluctuating antibody pattern during long-standing HCV infection (18) could explain the disparity between serological and molecular studies in seronegative/HCV RNA-positive patients. Our results strongly suggest that detection of anti-HCV in patients with HCC implies active HCV infection.

The amplification of HBV has enabled us to detect HBV DNA sequences in serum in 24 of the 66 patients tested (36\%). Twelve of the $24 \mathrm{HBV}$ DNA-positive patients were $\mathrm{HBsAg}$ negative and 5 were negative for all HBV serological markers. With PCR techniques, low levels of HBV DNA have been reported in patients with $\mathrm{HCC}$ and other liver diseases and with no serological markers of active HBV infection (19-22). Recently, Liang et al. (23) demonstrated serum HBV particles in $29 \%$ and $31 \%$ of HBsAg-negative patients with and without antibodies to $\mathrm{HBS}$ and $\mathrm{HBc}$, respectively. Although it is not possible to rule out the detection of integrated HBV DNA sequences from contaminating debris of necrotizing liver cells in the serum, PCR is considered the most sensitive diagnostic assay of HBV replication, and the presence of HBV-DNA in serum correlates with viremia (24). The reliability of the PCR results has been confirmed in experiments inducing HBV or "HBV variant" hepatitis in chimpanzees by inoculation of sera from these HBsAg-negative/HBV DNA-positive patients $(25,26)$. Thus the role of HBV infection in the development of $\mathrm{HCC}$ is not limited to the HBsAg-positive patients. Mechanisms by which HBV may contribute to the pathogenesis of liver cancer include induction of cirrhosis and HBV DNA integration into the hepatocyte genome and modification of cellular gene expression by insertional mutagenesis (27), chromosomal rearrangements (28) or by the transcriptional transactivating activity of the $\mathrm{X}$ and pre-S-S regions of the HBV genome (29-31).

Coinfection by HBV and HCV has been found in 9 of the 63 patients (14\%) in whom study of the two viruses was possible. It is remarkable that none of these patients was HBsAg positive. In fact, we have not found simultaneous positivities of HBsAg and anti-HCV and/or HCV-RNA in our series. These results are discrepant from previous reports from the United States and Mediterranean countries (32-34) but similar to those obtained in Japan and Taiwan $(6,35,36)$. We have no explanation for these differences except for the use in this work of a second-generation HCV ELISA that has probably reduced the number of false-positive results.

Some authors have speculated on possible interactions between $\mathrm{HBV}$ and $\mathrm{HCV}(22,23)$ that could influence the natural course of each separate viral disease. In this series no clinical differences suggestive of a more aggressive clinical course were observed between those patients with coinfection and the remaining patients. Thus possible pathogenetic implications of coinfection by the two viruses remain to be established and future studies, including a search for liver HBV DNA, will probably increase the prevalence of coinfection above the $14 \%$ reported here.

In conclusion, in our study $\mathrm{HCV}(62 \%)$ was more prevalent than HBV $(36 \%)$ in serum of patients with HCC. Taking together the serological and PCR results, $\mathrm{HBV}$ and $\mathrm{HCV}$ are implicated in the development of the tumor in 62 of the 70 patients (89\%) studied. Cirrhosis was present in all but one of the patients with virusrelated $\mathrm{HCC}$ and in four of the eight remaining nonviral tumors (three of alcoholic origin and one due to idiopathic hemochromatosis). Only in four patients (6\%) could no risk factors be identified in relation to the development of the tumor. These data emphasize the importance of effective antiviral treatment and programs of HBV vaccination and development of HCV 
vaccines, to decrease the incidence of $\mathrm{HCC}$, and the need for an adequate screening program for the early diagnosis of HCC in patients with cirrhosis.

Acknowledgments: We thank Celia Asensio and Edurne Elizalde for excellent technical assistance.

\section{REFERENCES}

1. Shafritz DA, Sherman M, Tur-Kaspa R. Hepatitis B virus persistence, chronic liver disease, and primary liver cancer. In: Zakim D, Boyer TD, eds. Hepatology: a textbook of liver disease. Philadelphia: W.B. Saunders Co., 1990:945-958.

2. Choo QL, Kuo G, Weiner AJ, Overby LR, Bradley DW, Houghton $M$. Isolation of a cDNA clone derived from a blood-borne non-A, non-B viral hepatitis genome. Science 1989;244:359-362.

3. Bruix J, Barrera JM, Calvet X, Ercilla G, Costa J, Sanchez-Tapias JM, Ventura M, et al. Prevalence of antibodies to hepatitis C virus in Spanish patients with hepatocellular carcinoma and hepatic cirrhosis. Lancet 1989;2:1004-1006.

4. Colombo M, Kuo G, Choo QL, Donato MF, Del Ninno E, Tommasini MA, Dioguardi N, et al. Prevalence of antibodies to hepatitis $\mathrm{C}$ virus in Italian patients with hepatocellular carcinoma. Lancet 1989;2:1006-1008.

5. Saito I, Miyamura T, Ohbayashi A, Harada H, Katayama T, Kikuchi S, Watanabe Y, et al. Hepatitis C virus infection is associated with the development of hepatocellular carcinoma. Proc Natl Acad Sci USA 1990;87:6547-6549.

6. Tanaka K, Hirohata T, Koga S, Sugimachi K, Kanematsu T, Ohryohji F, Nawata $H$, et al. Hepatitis $C$ and hepatitis $B$ in the etiology of hepatocellular carcinoma in the Japanese population. Cancer Res 1991;51:2842-2847.

7. Riezu-Boj JI, Parker D, Civeira MP, Phippard D, Corbisley TP, Camps J, Castilla A, et al. Detection of hepatitis C virus antibodies with new recombinant antigens: assessment in chronic liver diseases. J Hepatol 1992;15:309-313.

8. Galibert F, Mandart E, Fitoussi F, Tiollais P, Charnay P. Nucleotide sequence of the hepatitis $B$ virus genome (subtype ayw) cloned in E. coli. Nature 1979;281:646-650.

9. Garson JA, Tuke PW, Makris M, Briggs M, Machin SJ, Preston FE, Tedder RS. Demonstration of viraemia patterns in haemophiliacs treated with hepatitis $\mathrm{C}$ virus contaminated factor VIII concentrates. Lancet 1990;336:1022-1025.

10. Kwok S, Higuchi R. Avoiding false positives with PCR. Nature 1989;339:237-238.

11. Ayoola EA, Odelola HA, Johnson AOK. Primary liver cancer (PLC) after non-A, non-B hepatitis (NANBH) [Abstract]. HePATOLOGY $1982 ; 2: 154$.

12. Resnick RH, Stone K, Antonioli D. Primary hepatocellular carcinoma following non-A, non-B posttransfusion hepatitis. Dig Dis Sci 1983;28:908-911.

13. Dienstag JL. Non-A, non-B hepatitis. I. Recognition, epidemiology, and clinical features. Gastroenterology 1983;85:439-462.

14. Gilliam JH, Geisinger KR, Richter JE. Primary hepatocellular carcinoma after chronic non-A, non-B post-transfusion hepatitis. Ann Intern Med 1984;101:794-795.

15. Sakamoto $M$, Hirohashi $S$, Tsuda $H$, Ino $Y$, Shimosato $Y$, Yamasaki S, Makuuchi M, et al. Increasing incidence of hepatocellular carcinoma possibly associated with non-A, non-B hepatitis in Japan, disclosed by hepatitis B virus DNA analysis of surgically resected cases. Cancer Res 1988;48:7294-7297.

16. Kuo G, Choo QL, Alter HJ, Gitnick GL, Redeker AG, Purcell RH, Miyamura $\mathrm{T}$, et al. An assay for circulating antibodies to a major etiologic virus of non-A, non-B hepatitis. Science 1989;244: 362-364.

17. Kiyosawa K, Sodeyama T, Tanaka E, Gibo Y, Yoshizawa K, Nakano Y, Furuta S, et al. Interrelationship of blood transfusion, non-A, non-B hepatitis and hepatocellular carcinoma: analysis by detection of antibody to hepatitis C virus. HEPATOLOGY 1990;12: 671-675.

18. Farci P, Alter HJ, Wong D, Miller RH, Shih JW, Jetl B, Purcell RH. A long term study of hepatitis $C$ virus replication in non-A, non-B hepatitis. N Engl J Med 1991;25:98-104.
19. Thiers V, Nakajima E, Krensdorf D, Macke D, Schellekens H, Driss $F$, Goudeau $A$, et al. Detection and cloning by the polymerase chain reaction of hepatitis $B$ virus (HBV) DNA sequences in blood samples negative for HBV serologic markers. Lancet 1988;2:12731276.

20. Kaneko S, Miller RH, Feinstone SM, Unoura M, Kobayashi K, Hattori N, Purcell RH. Detection of hepatitis B virus DNA using the polymerase chain reaction assay. Proc Natl Acad Sci USA 1989;86:312-316.

21. Lai MY, Chen PJ, Yang PM, Sheu JC, Sung JL, Chen DS. Identification and characterization of intrahepatic hepatitis $B$ virus DNA in HBsAg-seronegative patients with chronic liver disease and hepatocellular carcinoma in Taiwan. HePATOLOGY 1990;12:575-581.

22. Paterlini P, Gerken G, Nakajima E, Terre S, D’Errico A, Grigioni W, Nalpas B, et al. Polymerase chain reaction to detect hepatitis $B$ virus DNA and RNA sequences in primary liver cancers from patients negative for hepatitis B surface antigen. N Engl J Med 1990;323:80-85.

23. Liang TJ, Baruch Y, Ben-Porath E, Enat R, Bassan L, Brown NV, Rimon $\mathbf{N}$, et al. Hepatitis $B$ virus infection in patients with idiopathic liver disease. HePaTOLOGY 1991;13:1044-1051.

24. Gerken G, Paterlini P, Manns M, Housset Ch, Terre S, Dienes HP, Hess $G$, et al. Assay of hepatitis B virus DNA by polymerase chain reaction and its relationship to pre-S- and S-encoded viral surface antigens. HEPATOLOGY 1991;13:158-166.

25. Thiers V, Kremsdorf D, Schellekens H, Goudeau A, Sninsky J, Nakajima E, Mack D, et al. Transmission of hepatitis B from hepatitis-B-seronegative subjects. Lancet 1988;2:12731276.

26. Liang TJ, Blum HE, Wands JR. Characterization and biological properties of a hepatitis B virus isolated from a patient without hepatitis B virus serologic markers. HePATOLOGY 1990; 12:204-212.

27. Nakamura T, Tokino T, Nagaya T, Matsubara K. Microdeletion associated with the integration process of hepatitis B virus DNA. Nucleic Acids Res 1988;16:4865-4873.

28. Tokino T, Fukushige S, Nakamura T, Nagaya T, Murotsu T, Shiga $\mathrm{K}$, Naoto A, et al. Chromosomal translocation and inverted duplication associated with integrated hepatitis B virus in hepatocellular carcinomas. J Virol 1987;61:3848-3854.

29. Takada S, Koide K. Trans-activation function of a $3^{\prime}$ truncated X gene-cell fusion product from integrated hepatitis B virus DNA in chronic hepatitis tissues. Proc Natl Acad Sci USA 1990;87:5628. 5632.

30. Wu JY, Zhou ZY, Judd A, Cartwright CA, Robinson WS. The hepatitis $B$ virus-encoded transcriptional trans-activator $\mathrm{Hbx}$ appears to be a novel protein serine/threonine kinase. Cell 1990;63:687-695.

31. Kekule AS, Lauer U, Meyer M, Caselmann WH, Hofschneider H, Koshy $R$. The preS/S region of integrated hepatitis B virus DNA encodes a transcriptional transactivator. Nature 1990;343: 457-461.

32. Yu MC, Tong MJ, Coursaget P, Ross RK, Govindarajan S, Henderson BE. Prevalence of hepatitis $B$ and $C$ viral markers in black and white patients with hepatocellular carcinoma in the United States. J Natl Cancer Inst 1990;82:1038-1041.

33. Nalpas B, Driss F, Pol S, Hamelin B, Housset C, Brechot C, Berthelot $\mathrm{P}$. Association between $\mathrm{HCV}$ and $\mathrm{HBV}$ infection in hepatocellular carcinoma and alcoholic liver disease. J Hepatol 1991;12:70-74.

34. Kaklamani E, Trichopoulos D, Tzonou A, Zavitsanos X, Koumantaki $Y$, Hatzakis A, Hsieh CC, et al. Hepatitis B and C viruses and their interaction in the origin of hepatocellular carcinoma. JAMA 1991;265:1974-1976.

35. Nishioka K, Watanabe J, Furuta S, Tanaka E, Iino S, Suzuki H, Tsuji T, et al. A high prevalence of antibody to the hepatitis $\mathrm{C}$ virus in patients with hepatocellular carcinoma in Japan. Cancer 1991;67:429-433.

36. Chen DS, Kuo GC, Sung JL, Lai MY, Sheu JC, Chen PJ, Yang PM, et al. Hepatitis $C$ virus infection in an area hyperendemic for hepatitis $B$ and chronic liver disease: the Taiwan experience. $J$ Infect Dis $1990 ; 162: 817-822$. 